\title{
PERBEDAAN FREKUENSI REGURGITASI PADA BAYI USIA 0-6 BULAN ATERM YANG DIBERI ASI EKSKLUSIF DAN SUSU FORMULA DI WILAYAH KERJA PUSKESMAS BALONGSARI KOTAMADYA MOJOKERTO
}

\author{
Indah Serinurani ${ }^{1}$, Fanny Ardie $^{2}$, Prasodjo ${ }^{3}$ \\ Puskesmas Kendal Kerep Kota Malang
}

\begin{abstract}
ABSTRAK
Latar Belakang : Regurgitasi merupakan kondisi normal yang dialami bayi tetapi jika berlebihan dan tidak ditangani bisa mengakibatkan komplikasi dan terganggunya pertumbuhan bayi. Tujuan : Mengetahui perbedaan frekuensi regurgitasi pada bayi usia 0-6 bulan aterm yang diberi ASI dan susu formula. Metode penelitian : Penelitian ini merupakan penelitian analitik observasional dengan menggunakan pendekatan studi cross sectional menggunakan uji hipotesa Rank Spearmans dan uji T-test. Hasil : Dalam penelitian ini didapatkan hasil bahwa dari 98 bayi dalam populasi hanya 22 bayi yang mengkonsumsi ASI eksklusif dan 45 bayi mengkonsumsi susu formula, setelah melalui random diambil 22 bayi tiap kelompok $(\mathrm{n}=44)$. Setelah dilakukan penilaian dengan kuisioner dari 22 bayi yang mengkonsumsi ASI eksklusif terdapat 15 bayi $(68,2 \%)$ mengalami regurgitasi sekali dalam sehari,7 bayi $(31,8 \%)$ mengalami regurgitasi lebih dari sekali dalam sehari, sedangkan bayi yang mengkonsumsi susu formula terdapat 5 bayi (22,7\%) mengalami regurgitasi sekali dalam sehari, 17 bayi $(77,3 \%)$ mengalami regurgitasi lebih dari sekali dalam sehari. Hasil uji Rank Spearmans didapatkan sign. $0.006(<0.01)$, uji T-test didapatkan sign. $0.02(<0.05)$. Kesimpulan : Terdapat hubungan antara konsumsi susu formula dengan peningkatan frekuensi regurgitasi $(\mathrm{P}=<0.01)$ dimana pemberian susu formula dapat meningkatkan frekuensi regurgitasi. Terdapat perbedaan frekuensi regurgitasi antara bayi yang mengkonsumsi ASI eksklusif dengan susu formula $(\mathrm{P}=<0.05)$ dimana bayi yang mengkonsumsi susu formula mempunyai tingkat frekuensi regurgitasi yang lebih tinggi dibandingkan bayi yang mengkonsumsi ASI eksklusif
\end{abstract}

Kata Kunci: Frekuensi Regurgitasi, ASI Eksklusif Dan Susu Formula

\begin{abstract}
Background : Regurgitation represent natural by normal condition of baby but if abundant and do not handle can result complication and annoyed of growth baby.

Target : For knowing the differential of frequency regurgitation at baby age 0-6 months of aterm by given is ASI and milk of formula. Research Method : This research is observasional analytic by using approach a cross-sectional study with hypothesizing test of Rank Spearman's and test of TTest. Result : In this research we got a result of that from 98 baby in population only 22 baby which consuming exclusive ASI and 45 baby consume milk of formula, after passing process of random we take 22 baby each lot $(n=44)$. After by assessment with quisioner from 22 baby which consuming exclusive ASI there are 15 baby $(68,2 \%)$ experiencing of regurgitation once in one day, 7 baby (31,8\%) experiencing of regurgitation more than once in one day, while baby which consuming milk of formula there are 5 baby $(22,7 \%)$ experiencing of regurgitation once in one day, 17 baby $(77,3 \%)$ experiencing of regurgitation more than once in one day. Result of Rank Spearman's test we got Significant at $0.006(<0.01)$, from T-test we got Significant at 0.02 (<0.05). Conclusion: There are relation between milk consumption of formula with make-up of frequency of regurgitation $(P=<0.01)$ where giving of milk of formula can improve frequency of regurgitation. There are difference of frequency of regurgitation between baby which consuming exclusive ASI with milk of formula $(P=<0.05)$ where baby which consuming milk of formula bave frequency storey level of regurgitation compared to bigher level of baby which consuming exclusive ASI.
\end{abstract}

Key Words : Frequency of regurgitation, Exclusive ASI and milk of formula 


\section{PENDAHULUAN}

Air Susu Ibu (ASI) adalah makanan terbaik dan alamiah untuk bayi. Menyusui merupakan suatu proses alamiah, namun sering ibu-ibu tidak berhasil menyusui atau menghentikan menyusui lebih dini dari yang semestinya. Banyak alasan yang dikemukakan ibu-ibu antara lain, ibu merasa bahwa ASI nya tidak cukup, atau ASI tidak keluar pada hari-hari pertama kelahiran bayi. Sesungguhnya hal itu disebabkan karena ibu tidak percaya diri bahwa ASI nya cukup untuk bayinya. Disamping informasi tentang caracara menyusui yang baik dan benar belum menjangkau sebagian besar ibu-ibu (Depkes, 2002).

Sejak lahir, bayi seharusnya hanya diberi ASI saja sampai usia bayi 6 bulan. Selanjutnya pemberian ASI diteruskan hingga anak berusia 2 tahun, dengan penambahan Makanan Pendamping ASI (MP-ASI) yang sesuai dengan umur bayi (Depkes, 2002).

Apabila pada periode ini, bayi dipaksa menerima makanan selain ASI, maka akan timbul gangguan kesehatan pada bayi seperti diare, alergi dan bahaya lain yang fatal. Tanda bahwa ASI eksklusif memenuhi kebutuhan bayi antara lain : bayi tidak rewel, dan tumbuh sesuai grafik pada kartu menuju sehat (Depkes, 2003).

ASI eksklusif atau lebih tepat pemberian ASI secara ekslusif adalah bayi hanya diberi ASI saja, tanpa tambahan cairan lain seperti susu formula, jeruk, madu, air teh, air putih, dan tanpa penambahan makanan padat seperti pisang, pepaya, bubur susu, biskuit, bubur nasi, dan tim dalam jangka waktu sampai 6 bulan, setelah bayi berumur 6 bulan, ia harus mulai diperkenalkan dengan makanan padat, sedangkan ASI dapat diberikan sampai bayi berusia 2 tahun (Roesli U, 2000).

Pada saat ini puluhan macam susu formula beredar di pasaran. Umumnya bahan dasar susu formula adalah susu sapi tetapi sebagian ada juga terbuat dari susu kedelai, ditambah bahan-bahan lainnya. Susu formula diproduksi secara khusus sebagai makanan bayi. Kini, kebudayaan menyusui dengan ASI yang telah berusia sama dengan peradaban manusia itu sendiri semakin terdesak oleh kebudayaan susu botol, yang usianya dapat dikatakan baru kemarin sore kalau dibandingkan dengan ASI (Winarno, 1995).

Barangkali karena gencarnya promosi dan iklan yang luar biasa efektifnya, kita terpukau oleh gemerlapnya iklan susu botol. Kini susu botol sudah menyebar ke seluruh lapisan masyarakat, baik yang mampu ataupun kurang mampu. Kegagalan menyusui anak bukan hanya merupakan masalah masyarakat pedesaan masa kini, tetapi juga merupakan masalah serius masyarakat perkotaan. Kegagalan menyusui anak merupakan faktor yang merusak kesehatan dan gizi bayi (Suhardjo, 2002).

Di daerah pedesaan, pada umumnya ibu menyusui bayi mereka, namun hasil penelitian menunjukkan bahwa pengaruh kebiasaan yang kurang baik, seperti pemberiaan makanan pralaktal yaitu pemberian makanan/minuman untuk menggantikan ASI apabila ASI belum keluar pada hari-hari pertama setelah kelahiran. Jenis makanan tersebut antara lain air tajin, air kelapa, madu yang dapat membahayakan kesehatan bayi dan menyebabkan berkurangnya kesempatan untuk merangsang produksi ASI sedini mungkin melalui isapan bayi pada payudara ibu. Disamping itu masih banyak ibu-ibu tidak memanfaatkan kolostrum ( ASI yang keluar pada hari-hari pertama), karena dinggap tidak baik untuk makanan bayi, susu basi, dll. Selanjutnya pemberian makanan pendamping ASI (MPASI) diberikan tidak tepat waktu (terlalu dini atau terlalu lambat) serta tidak menyukupi baik kuantitas maupun kualitasnya (Depkes, 2002).

Dari Survey Demografi Kesehatan Indonesia 1997 dan 2002 membuktikan perilaku pemberian ASI di negeri ini tidak menggembirakan. Pada tahun 1997 jumlah ibu yang menyusui bayinya mencapai $96,3 \%$, angka itu turun menjadi $95,5 \%$ pada tahun 2002. Sementara jumlah ibu yang menyusui anaknya pada periode emas ( satu jam pertama setelah kelahiran ) hanya 3\%. Pemberian ASI eksklusif ( hanya ASI tanpa tambahan susu formula dan bahan makanan lainnya ) setelah enam bulan pertama pasca lahir pada tahun 1997 hanya 42,4\% dan turun menjadi 39.5\% pada tahun 2002 (Depkes, 2007).

Penelitian yang sama menunjukkan bahwa 18,7\% dari ibu-ibu yang dianjurkan oleh petugas kesehatan untuk memberi susu formula pada minggu pertama setelah kelahiran. Sebagian besar ibu menyatakan bahwa sumber promosi-promosi susu formula adalah pelayanan kesehatan (76\%) dimana 21\% ibu melihat iklan susu formula di Rumah Sakit, 19,5\% di praktek klinik swasta dan 19,5\% di puskesmas. Lebih jauh lagi, lebih dari 60\% ibu-ibu menyatakan menerima susu formula melalui Rumah Sakit atau Rumah Bersalin, dan sekitar 40\% ibu menerima hadiah dari perusahaan susu formula untuk bayi. Temuan penting lainnya dari studi tersebut adalah bahwa 14,8\% bidan menyatakan setuju untuk memberikan susu formula kepada bayi baru lahir (Depkes, 2002). Padahal banyak sekali gangguan akibat ketidakcocokan pemberian susu formula pada bayi anda. Tanda dan gejala ketidakcocokan susu formula atau alergi susu hampir sama dengan alergi makanan. Gangguan tersebut dapat mengganggu semua organ tubuh terutama pencernaan (sering muntah/gumoh, kembung, sering buang air besar), kulit (sering timbul bintik atau bisul kemerahan terutama di pipi, telinga dan daerah yang tertutup popok), saluran napas dan organ lainnya (Muzal K, 2007).

Regurgitasi adalah keluarnya kembali (tumpah, gumoh) susu yang telah ditelan ketika atau beberapa saat setelah minum susu botol atau menyusu dan jumlahnya hanya sedikit (Rusepno H \& Husein A, 1985).

Gumoh adalah kondisi normal yang biasa terjadi pada bayi tetapi jika berlebihan dan tidak ditangani bisa mengakibatkan komplikasi dan terganggunya pertumbuhan bayi. Di Indonesia 70\% bayi berumur kurang dari empat bulan dipastikan mengalami gumoh minimal sekali sehari. Kejadian itu mengalami penurunan seiring dengan bertambahnya usia bayi. Walau begitu, ternyata hanya sekitar $25 \%$ orang tua bayi yang peduli dan menganggap gumoh sebagai sebuah masalah (Badriul H, 2005).

Regurgitasi disebabkan karena sistem pencernaan bayi yang masih belum sempurna. Otot di esophagus (saluran antara kerongkongan dan perut) masih belum menutup dengan baik. Karena saluran ini terbuka, maka isi perut dapat dengan mudah keluar kembali keatas (Wyeth, 2007). 
Hubungan antara pemberian ASI dengan susu formula terhadap efek regurgitasi disebabkan karena adanya perbedaan susunan lemak pada ASI dan susu formula. Pada ASI mengandung asam lemak tak jenuh yang lebih cepat diserap alat pencernaan bayi sedangkan susu formula mengandung asam lemak jenuh yang lama diserap alat pencernaan (Diah K \& Rina Y, 2002).

\section{METODE}

Desain penelitian yang digunakan dalam penelitian ini adalah analitik observasional dengan menggunakan pendekatan study cross sectional. Penelitian ini dilakukan di Posyandu di wilayah kerja Puskesmas Balongsari (Kelurahan Balongsari dan Kelurahan Jagalan) Kotamadya Mojokerto selama +1 bulan atau sampai tercapainya sampel.

Populasi pada penelitian ini adalah bayi yang berusia 0 6 bulan aterm dengan $\mathrm{BBL}>2,5 \mathrm{~kg}$ di wilayah kerja Puskesmas Balongsari Kotamadya Mojokerto.

Sampel yang digunakan dalam penelitian ini adalah semua anggota populasi yang sesuai dengan kriteria inklusi dan tidak sesuai kriteria eksklusi.

Kriteria inklusi dalam penelitian ini meliputi: Bayi yang berusia 0-6 bulan aterm (cukup bulan) dengan BBL $>2,5$ $\mathrm{kg}$, bayi yang hanya diberi ASI eksklusif, bayi yang hanya diberi susu formula dan bayi yang orang tua (ibu) bersedia menjadi responden. Sedangkan kriteria eksklusi dalam penelitian ini yakni: bayi yang diberi ASI dan susu formula, bayi yang diberi makanan pendamping ASI, dan bayi prematur

Tehnik pengambilan sampel dalam penelitian ini adalah menggunakan quota sampel yaitu bayi yang mengkonsumsi ASI eksklusif sebanyak 22 bayi sedangkan bayi yang mengkonsumsi susu formula sebanyak 45 bayi. Untuk tercapainya homogenitas untuk bayi yang mengkonsumsi susu formula dijadikan 22 bayi.

Penelitian ini menggunakan instrumen kuisioner untuk mengetahui pemahaman atau persamaan persepsi tentang gumoh. Tingkat pengetahuan diukur dengan menilai skor dari jawaban hasil kuisioner. Penilaian dilakukan dengan cara membandingkan jumlah skor jawaban dengan skor yang diharapkan (tertinggi) kemudian dikalikan 100\% dan hasilnya berupa prosentase.

Suatu alat tes atau instrumen pengukur dapat dikatakan mempunyai validitas yang tinggi apabila alat tersebut menjalankan fungsi ukurnya. Validitas adalah ukuran seberapa tepat dan cermat suatu alat tes dalam melakukan fungsi ukurnya.

Validitas empirik dinyatakan dalam koefisien validitas. Semakin mendekati nilai 1,0 maka semakin valid hasil ukurnya (Azwar, 2006).

Untuk mengukur kesahihan atau validitas item maka rumus korelasi yang digunakan adalah tehnik Product Moment dari Karl Pearson.

Reliabilitas suatu alat tes dapat diketahui jika alat tersebut mampu menunjukkan sejauh mana pengukurannya dapat memberikan hasil yang dapat dipercaya bila dilakukan kembali terhadap subyek yang sama (Azwar, 2006). Tinggi rendahnya reliabilitas diunjukkan oleh koefisien reliabilitas yang dilambangkan dengan huruf r. untuk menunjukkan reliabilitas alat ukur maka digunakan bantuan komputer seri program statistik (SPSS). Uji reliabilitas dilakukan dengan rumus Alpha karena penilaian skornya merupakan rentangan antara beberapa nilai.

Penilaian dalam kuesioner untuk mengetahui tingkat pemahaman tentang gumoh. Kuisioner disusun berdasarkan struktur yakni tahu (know), memahami (comprehension), aplikasi (application), analisis (analysis), sintesis (synthesis), evaluasi (evaluation)

Tahu diartikan sebagai mengingat suatu materi yang telah dipelajari sebelumnya. Termasuk mengingat kembali (recall) terhadap sesuatu yang spesifik dari seluruh bahan yang dipelajari atau rangsangan yang telah diterima. Kriteria orang yang tahu adalah bisa menyebutkan, menguraikan, mendefinisikan dan menyatakan sesuatu.

Memahami diartikan sebagai suatu kemampuan untuk menjelaskan secara benar tentang obyek yang diketahui dan dapat menginterprestasikan materi tersebut secarabenar. Kriterianya harus dapat menjelaskan, menyebutkan contoh, menyimpulkan dan meramalkan terhadap obyek yang dipelajari.

Aplikasi diartikan sebagai kemampuan untuk menggunakan materi yang telah dipelajari pada situasi dan kondisi yang nyata atau sebenarnya.

Analisis adalah suatu kemampuan untuk menjabarkan materi atau suatu obyek ke dalam komponen-komponen tetapi masih dalam satu struktur organisasi dan masih ada kaitannya satu sama lain. Kemampuan analisis ini dapat dilihat dari kemampuan menggambarkan (membuat bagan), membedakan, memisahkan, mengelompokkan dan sebagainya.

Sintesis menunjuk pada suatu kemampuan untuk meletakkan atau menghubungkan bagian-bagian dalam bentuk keseluruhan yang baru.

Evaluasi ini berkaitan dengan kemampuan untuk melakukan justifikasi atau penilaian terhadap suatu materi atau obyek berdasarkan suatu kriteria yang ditentukan sendiri atau yang telah ada (Notoatmodjo, S, 2003).

Pengumpulan data yang dilakukan oleh peneliti adalah dengan metode wawancara dan angket (kuisioner) untuk mengetahui umur bayi, konsumsi ASI eksklusif atau susu formula dan frekuensi regurgitas.

Hasil wawancara dan kuisioner serta data-data yang sudah didapat, datanya diolah dalam bentuk tabel distribusi dan prosentase frekuensi, dianalisa menggunakan uji Rank Spearmans untuk melihat hubungan antara pemberian ASI dan susu formula dengan regurgitasi. Dan uji $\mathrm{T}$ untuk melihat perbedaan frekuensi regurgitasi pada bayi usia 0-6 bulan yang diberi ASI dan susu formula. Diolah menggunakan bantuan komputer dengan program SPSS.

\section{HASIL DAN PEMBAHASAN}

Total jumlah populasi dalam penelitian ini berjumlah 98 bayi. Bayi yang sesuai kriteria inklusi sebanyak 67 bayi dan yang sesuai dengan kriteria eksklusi sebanyak 31 bayi dengan rincian 2 bayi BBLR <2500 gr dan 29 bayi mengkonsumsi ASI dan Susu Formula. Bayi yang 
mengkonsumsi ASI eksklusif sebanyak 22 bayi dan bayi yang mengkonsumsi susu formula saja sebanyak 45 bayi, kemudian untuk menjadikan sampel itu homogen dari 45 bayi yang mengkonsumsi susu formula di ambil 22 bayi dan diambil secara random.

Tabel 1. Distribusi konsumsi bayi

\begin{tabular}{lrccr}
\hline $\begin{array}{l}\text { Jumlah } \\
\text { Bayi }\end{array}$ & ASI & $\begin{array}{l}\text { Susu } \\
\text { Formula }\end{array}$ & $\begin{array}{l}\text { ASI } \\
\text { Formula }\end{array}$ & Susu \\
\hline 98 & 22 & 45 & 31 & \\
\hline
\end{tabular}

Instrumen yang digunakan dalam penelitian ini adalah kuisioner. Dimana sebelum dibagikan kepada sampel, kuisioner tersebut diuji validitas dan reliabilitasnya. Uji ini dilakukan pada 30 orang sampel. Hasil uji kesahihan atau validitas item dengan menggunakan tehnik Product Moment dari Karl Pearson.

Tabel 2. Hasil uji validitas

\begin{tabular}{llll}
\hline $\begin{array}{l}\text { No } \\
\text { Item }\end{array}$ & $\mathbf{R}$ tabel & $\begin{array}{l}\text { Indeks } \\
\text { validitas }\end{array}$ & Keterangan \\
\hline C1 & 0,361 & 0,748 & valid \\
C2 & 0,361 & 0,529 & valid \\
C3 & 0,361 & 0,664 & valid \\
C4 & 0,361 & 0,570 & valid \\
C5 & 0,361 & 0,630 & valid \\
C6 & 0,361 & 0,571 & valid \\
C7 & 0,361 & 0,475 & valid \\
C8 & 0,361 & 0.501 & valid \\
C9 & 0,361 & 0,703 & valid \\
C10 & 0,361 & 0,854 & valid \\
C11 & 0,361 & 0,703 & valid \\
C12 & 0,361 & 0,756 & valid \\
C13 & 0,361 & 0,499 & valid \\
C14 & 0,361 & 0,594 & valid \\
C15 & 0,361 & 0,708 & valid \\
\hline
\end{tabular}

Tabel menunjukkan seluruh item pertanyaan dari variabel pengetahuan valid karena nilai koefisien korelasi lebih dari 0,361. Nilai koefisien korelasi tertinggi pada item pertanyaan ke-10 tentang "Apa yang harus anda lakukan pada saat bayi mengalami gumoh”, sedangkan koefisien korelasi terendah pada item pertanyaan ke-7 tentang "Bagaimana perbandingan jumlah cairan yang keluar dari mulut bayi dengan susu yang diminum”.

Hasil uji reliabilitas tingkat pengetahuan menggunakan nilai koefisien Reliabilitas Alpha sebagai berikut :
Tabel 3. Hasil uji Reliabilitas

\begin{tabular}{llll}
\hline Indikator & R tabel & Alpha & Keterangan \\
\hline Tingkat & 0,3 & 0,89 & \\
Pengetahuan & 61 & 49 & Reliabel \\
\hline
\end{tabular}

Tabel menunjukkan nilai koefisien reliabilitas alpha variabel lebih besar dari 0,361 dinyatakan sudah reliabel (handal) karena nilai koefisien reliabilitas alpha variabel sebesar 0,8949 .

Untuk mengetahui frekuensi regurgitasi maka dilakukan pembagian kuisioner yang telah terlebih dahulu diuji dengan uji validitas dan reliabilitas kepada ibu bayi, kemudian juga dilakukan wawancara kepada ibu bayi untuk mengetahui kebenaran dari jawaban. Setelah itu data-data yang didapat diolah dalam bentuk distribusi frekuensi untuk mengetahui perbandingan tingkat frekuensi regurgitasi antara bayi yang diberi ASI eksklusif dengan bayi yang mengkonsumsi susu formula.

\begin{tabular}{|c|c|c|}
\hline & $1 \mathrm{X} / \mathrm{hr}$ & $>1 \mathrm{X} / \mathrm{hr}$ \\
\hline Asi & $15(68.2 \%)$ & $7(31.8 \%)$ \\
\hline
\end{tabular}

Susu Formula $5(22.7 \%) \quad 17(77.3 \%)$

Dari observasi awal dilapangan ternyata diwilayah kerja Puskesmas Balongsari-Mojokerto hanya sebagian kecil saja bayi yang mengkonsumsi ASI eksklusif, walaupun data dari dinas setempat tidak ada tapi dari hasil kuisioner dan wawancara yang dilakukan terhadap para ibu bayi ternyata sebagian besar dari mereka lebih memilih memberikan susu formula kepada bayi mereka dibandingkan ASI ekskulsif yang disebabkan oleh berbagai alasan.

Jumlah bayi yang berusia 0-6 bulan seluruhnya sebanyak 98 bayi, tetapi hanya 22 bayi $(22.4 \%)$ yang mendapatkan ASI eksklusif dan sisanya sebanyak 76 bayi $(77.6 \%)$ mendapatkan susu formula atau campuran antara ASI dan susu formula, sedangkan jumlah diatas tidak jauh berbeda dengan Survey Demografi Kesehatan Indonesia 1997 dan 2002 membuktikan perilaku pemberian ASI dinegeri ini tidak menggembirakan. Pemberian ASI eksklusif selama enam bulan pertama pasca lahir pada 1997 hanya 42,4\% dan turun menjadi 39,5\% pada tahun 2002 (Depkes, 2007). Dari hasil wawancara yang dilakukan terhadap para ibu ternyata hanya sebagian kecil saja dari mereka yang mengetahui manfaat memberikan ASI eksklusif kepada bayinya sedangkan sebagian besar dari para ibu menganggap jika anaknya tidak mendapatkan susu formula atau makanan maka anaknya tidak dapat gemuk, dan rata-rata mereka mulai memberikan susu formula saat bayi berusia 3 bulan karena dari data yang kami miliki tidak ditemukan bayi berusia dibawah 3 bulan yang mengkonsumsi susu formula.

Dari hasil wawancara kepada para ibu didapatkan beberapa alasan yang menyebabkan ibu memberikan susu formula kepada bayinya, antara lain: pekerjaan, tingkat pengetahuan, persepsi yang salah, 
Pekerjaan, sebagian para ibu beralasan tidak dapat memberikan ASI eksklusif kepada bayinya dikarenakan dia harus bekerja sehingga tidak punya waktu untuk menyusui, dari data yang ada sebanyak $14(63.6 \%)$ ibu dari bayi yang mengkonsumsi susu formula bekerja dan 8 (36.4\%) ibu yang tidak bekerja, sedangkan dari ibu bayi yang mengkonsumsi ASI eksklusif hanya 5 (22.7\%) orang yang bekerja dan $17(77.3 \%)$ ibu yang tidak bekerja.

Tingkat Pengetahuan, sebagian besar para ibu baik yang memberikan ASI eksklusif dan susu formula tidak mengetahui manfaat dan keunggulan memberikan ASI eksklusif kepada bayinya.

Salah Persepsi, Dari hasil wawancara ternyata banyak diantara para ibu yang memberikan susu formula kepada bayinya yaitu sebanyak 16 orang $(72.7 \%)$ beranggapan bahwa kalau tidak diberikan susu formula maka bayinya tidak dapat gemuk, dan mereka juga beranggapan bahwa bayi yang gemuk itu sehat atau tidak kurang gizi.

Para ibu yang memberikan ASI eksklusif juga memiliki beberapa alasan kenapa mereka hanya memberikan ASI eksklusi kepada bayinya, diantaranya karena alasan ekonomi dan tingkat pengetahuan yang baik

Ekonomi, sebagian besar para ibu memberikan ASI Eksklusif kepada bayinya karena alasan ekonomi, mereka keberatan atau tidak mampu untuk membeli susu formula.

Tingkat Pengetahuan, walaupun hanya sedikit, tapi ada beberapa ibu yang menganggap bahwa untuk bayinya memang lebih baik ASI eksklusif dari pada susu formula, dan mereka beranggapan bayi yang terlalu gemuk itu belum tentu sehat karena tidak lincah.

Untuk mengetahui hubungan antara konsumsi susu dengan regurgitasi maka terlebih dahulu dilakukan pengelompokan sampel, kelompok pertama adalah 22 bayi yang mengkonsumsi ASI eksklusif dan kelompok kedua adalah 22 bayi yang mengkonsumsi susu formula. Setelah dikelompokkan kemudian dilakukan penilaian dengan menggunakan kuisioner dan wawancara kepada para ibu mereka.

Dari hasil kuisioner dan wawancara yang dilakukan terhadap para ibu bayi diketahui bahwa sebagian besar baik bayi yang mengkonsumsi ASI atau susu formula rata-rata setiap hari mengalami regurgitasi, tetapi bayi yang mengkonsumsi susu formula sebagian besar mengalami regurgitasi lebih dari sekali dalam sehari, dari data yang didapatkan bayi yang mengalami regurgitasi lebih dari sekali dalam sehari sebanyak 17 bayi atau mencapai 77.3\%, sedangkan bayi yang mengalami regurgitasi sekali dalam sehari sebanyak 5 bayi atau hanya $22.7 \%$.

Perbandingan antara bayi yang mengalami regurgitasi lebih dari sekali dalam sehari dan yang mengalami regurgitasi sekali dalam sehari cukup besar yaitu 3.4:1, hal ini menunjukkan bahwa pada bayi yang mengkonsumsi susu formula sebagian besar mengalami regurgitasi lebih dari sekali dalam sehari dan hanya sebagian kecil saja yang mengalami regurgitasi sekali dalam sehari.

Dari data diatas dapat diketahui bahwa ada hubungan antara pemberian susu formula dengan peningkatan frekuensi regurgitasi, hal itu dikarenakan dari penelitian bayi yang mengkonsumsi susu formula mengalami peningkatan frekuensi regurgitasi yaitu lebih dari sekali dalam sehari sedangkan normalnya bayi mengalami regurgitasi sekali dalam sehari sehingga dapat disimpulkan bahwa pemberian susu formula pada bayi dapat menyebabkan peningkatan frekuensi regurgitasi.

Untuk lebih meyakinkan hasil penelitian maka dilakukan penghitungan uji hipotesa menggunakan uji Rank Spearmans dan didapatkan hasil adanya korelasi antara susu formula dengan terjadinya peningkatan frekuensi regurgitasi dimana didapatkan Sign. $0.006(<0,01)$, sehingga dapat dijelaskan bahwa ada hubungan antara pemberian susu formula dengan terjadinya peningkatan frekuensi regurgitasi.

Data-data serta penghitungan uji hipotesa diatas sudah dapat menjelaskan adanya hubungan antara susu formula dengan terjadinya peningkatan frekuensi regurgitasi dimana susu formula menyebabkan peningkatan frekuensi regurgitasi. Hasil penelitian ini serupa dengan yang dikemukakan oleh Muzal Karim bahwa banyak sekali gangguan akibat ketidakcocokan pemberian susu formula pada bayi anda. Tanda dan gejala ketidakcocokan susu formula atau alergi susu hampir sama dengan alergi makanan. Gangguan tersebut dapat mengganggu semua organ tubuh terutama pencernaan (sering muntah/gumoh, kembung, sering buang air besar), kulit (sering timbul bintik atau bisul kemerahan terutama di pipi, telinga dan daerah yang tertutup popok), saluran napas dan organ lainnya (Muzal K, 2007). Dalam penelitian ini juga didapatkan bahwa anak yang diberi susu formula mengalami peningkatan frekuensi regurgitasi.

Secara umum pola regurgitasi pada bayi yang mengkonsumsi ASI Eksklusif tidak jauh berbeda dengan bayi yang mengkonsumsi susu formula. Bayi yang mengkonsumsi ASI Eksklusif maupun susu formula semuanya pernah mengalami regurgitasi.

Dari hasil kuisioner dapat dijelaskan bahwa terdapat perbedaan frekuensi regurgitasi antara bayi yang diberi susu formula dan ASI Eksklusif, bayi yang diberi ASI Eksklusif rata-rata mengalami regurgitasi sekali dalam sehari yaitu sebanyak 15 bayi, 3 bayi mengalami regurgitasi dua kali dalam sehari, 3 bayi mengalami regurgitasi tiga kali dalam sehari dan hanya 1 bayi yang mengalami regurgitasi empat kali dalam sehari. Sedangkan bayi yang diberi susu formula mempunyai frekuensi regurgitasi yang lebih bervariasi yaitu 5 bayi mengalami regurgitasi dalam sehari, 8 bayi mengalami regurgitasi dua kali dalam sehari, 7 bayi mengalami regurgitasi tiga kali dalam sehari dan 2 bayi mengalami regurgitasi empat kali dalam sehari.

Normalnya bayi mengalami regurgitasi sekali dalam sehari dan bila lebih dari sekali dikatakan tidak normal, dan agar lebih memudahkan untuk melihat perbedaan frekuensi regurgitasi antara bayi yang diberi ASI Eksklusif dan susu formula maka dibuat klasifikasi menjadi sekali dalam sehari (normal) dan lebih dari sekali dalam sehari (tidak normal). Hasil kuisioner dan wawancara menunjukkan bahwa ratarata bayi yang diberi ASI Eksklusif yaitu 15 bayi (68.2\%) mengalami regurgitasi sekali dalam sehari dan yang mengalami regurgitasi lebih dari sekali dalam sehari sebanyak 7 bayi $(31,8 \%)$, sedangkan bayi yang diberi susu formula yaitu 5 bayi $(22,7 \%)$ mengalami regurgitasi sekali dalam sehari dan 17 bayi (77.3\%) mengalami regurgitasi lebih dari sekali dalam sehari. 
Dari data-data diatas dapat dijelaskan bahwa terdapat perbedaan frekuensi regurgitasi antara bayi yang diberi susu formula dan ASI Eksklusif, dimana frekuensi regurgitasi bayi yang diberi susu formula lebih tinggi daripada bayi yang diberi ASI Eksklusif. Kesimpulan tersebut didasarkan pada hasil penelitian yang menunjukkan bahwa rata-rata bayi yang diberi ASI Eksklusif (68,2\%) mengalami regurgitasi sekali dalam sehari sedangkan bayi yang diberi susu formula $(77,3 \%)$ mengalami regurgitasi lebih dari sekali dalam sehari.

Untuk lebih menyakinkan hasil penelitian maka dilakukan penghitungan uji hipotesa menggunakan uji TTest untuk melihat perbedaan frekuensi regurgitasi antara bayi yang diberi ASI Eksklusif dan susu formula. Dari hasil penghitungan T-test didapatkan hasil adanya perbedaan frekuensi regurgitasi antara bayi yang diberi ASI Eksklusif dan susu formula dimana didapatkan Sign. $0.02(<0.05)$. Sehingga dapat dijelaskan bahwa terdapat perbedaan frekuensi regurgitasi antara bayi yang diberi ASI Eksklusif dengan bayi yang diberi susu formula dimana bayi yang diberi susu formula mempunyai frekuensi regurgitasi yang lebih tinggi dari pada bayi yang diberi ASI Eksklusif.

Hasil penelitian ini sesuai dengan pernyataan Widodo. J yang menyatakan bahwa "susu formula (mengandung asam lemak jenuh) relatif sulit dicerna sistem pencernaan bayi". Sehingga sistem pencernaan bekerja lebih keras untuk memecah susu formula menjadi nutrien yang mudah diserap tubuh. Akibatnya butuh waktu yang lama untuk pengosongan lambung hingga terjadinya refluks asam dan terjadilah regurgitasi (Widodo J, 2006).

\section{SIMPULAN}

Terdapat perbedaan frekuensi regurgitasi antara bayi yang mengkonsumsi ASI Eksklusif dengan bayi yang mengkonsumsi susu formula, dimana rata-rata bayi yang mengkonsumsi ASI Eksklusif mengalami regurgitasi sekali dalam sehari sedangkan bayi yang mengkonsumsi susu formula mengalami regurgitasi lebih dari sekali dalam sehari.

\section{DAFTAR PUSTAKA}

Arikunto, S.: Prosedur Penelitian. PT. Rineka Cipta, Jakarta, 2002

Badriul, H.: Gumoh Bisa Ganggu Pertumbuhan Bayi, 2005. Diakses dari: www.google.com

Budi, S.: Cara Menyiapkan Susu Formula, 2006. Diakses dari: www.info-sehat.com

Depkes, RI.: Konsumsi Susu Anak-anak Indonesia Masib Rendah. Depkes, Jakarta, 2007

Depkes, RI.: Pedoman Umum Gizi Seimbang. Depkes, Jakarta, 2003

Depkes, RI.: Manajemen Laktasi. Depkes, Jakarta, 2002

Diah, K; Rina, Y.: Menyiapkan Makanan Pendamping ASI. Puspa Swara, Jakarta, Hal 4-13, 2002

Heru, S.: Regurgitasi, 2004. Diakses dari: www.google.com

Kishore, R.J.: Bayi Sering Gumoh, 2007. Diakses dari: www.google.com

Markum.: Ilmu Kesehatan Anak jilid 1. Balai Penerbit FKUI, Jakarta, Hal 138-144, 1999

Muzal, K.: Gumoh, 2007. Diakses dari: www.google.com
Nestle.: ASI Ditinjau Dari Beberapa Aspek. Nestle, Jakarta, 1992

Nelson.: Ilmu Kesehatan Anak bagian 1 edisi 12, Jakarta, Hal 276-288, 1988

Nursalam.: Pendekatan Praktis Metodologi Riset Keperawatan. Infomedika, Jakarta, 2000

Ramaiah, S.: ASI Dan Menyusui. PT. Bhuana Ilmu Populer, Jakarta, 2006

Roesli, U.: Mengenal ASI Ekesklusif. Trubus Agriwidya, Jakarta, 2000

Rusepno, H; Husein, A.: Buku Kuliah 1 Ilmu Kesehatan Anak, FKUI, Jakarta, Hal 320-329, 1985

Sastroasmoro, S.: Dasar-Dasar Metodologi Penelitian Klinis. Bina Rupa Aksara, Jakarta, 1995

Sabar.: Bayi Gumoh, Tak perlu Khawatir, 2007. Diakses'dari: www.google.com

Soetjiningsih.: ASI: Petunjuk Untuk Tenaga Kesehatan. EGC, Jakarta, Hal 16-29, 1997

Suhardjo.: Pemberian Makanan Pada Bayi Dan Anak. Kanisius, Yogyakarta, Hal 68-78; 98-106, 2002

Widodo, J.: Pemilihan Susu Formula Terbaik Bagi Anak, 2006. Diakses dari: www. childrenfamily.com

Winarno.: Gizi Dan Makanan Bagi Bayi Dan Anak Sapihan. Pustaka Sinar Harapan, Jakarta, Hal 75-90; 92-107, 1995 